Historic, Archive Document

Do not assume content reflects current scientific knowledge, policies, or practices. 



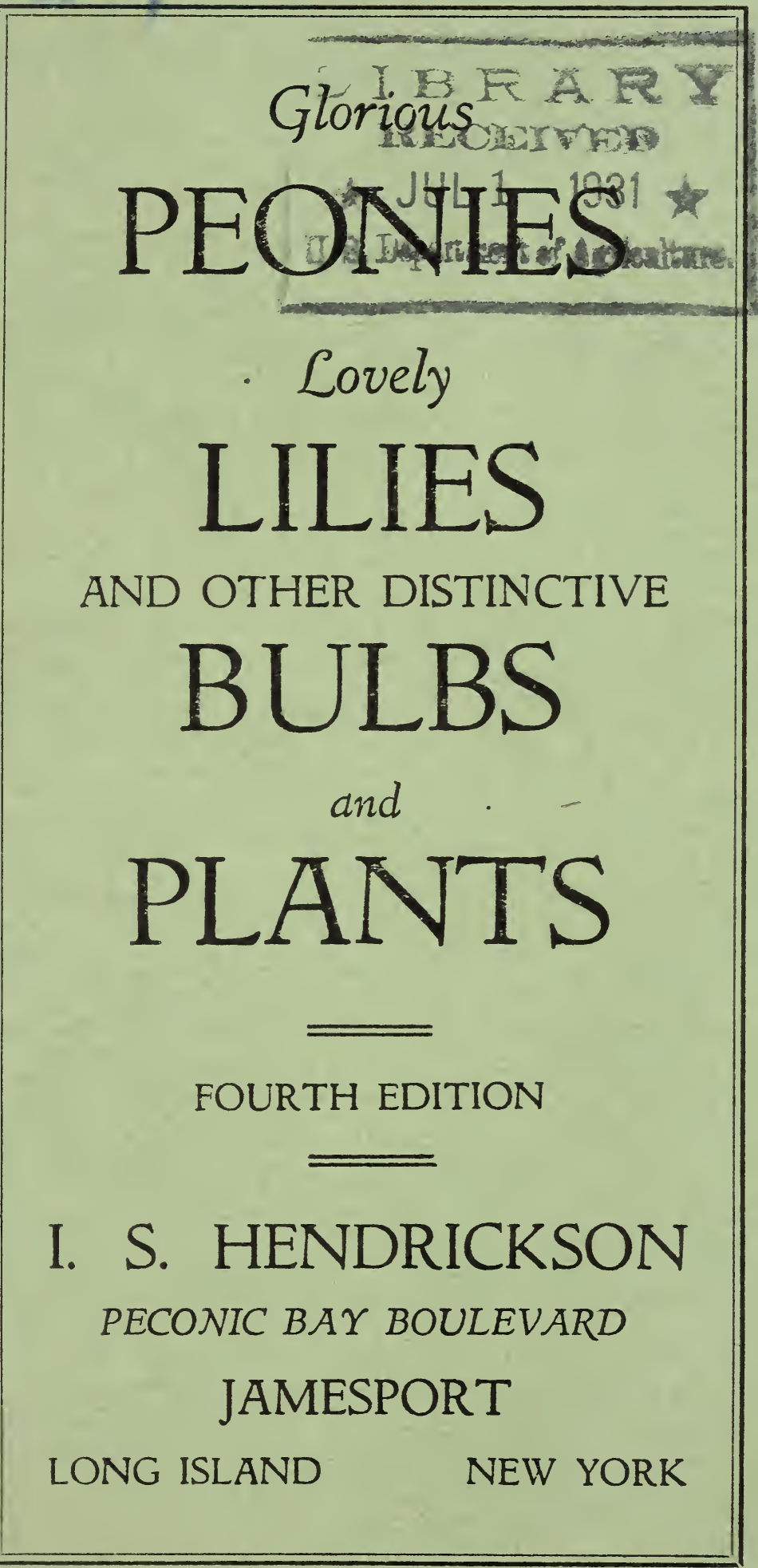




\section{Terms on Beony Roots}

Prices quoted are based on well balanced roots containing 3 to 5 eyes, the ideal size for planting.

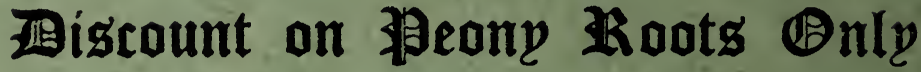

$$
\begin{aligned}
& 5 \% \text { on orders } \$ 10.00 \text { to } \$ 25.00 \\
& 10 \% \text { " " } 25.00 \text { " } 50.00 \\
& 15 \% \text { " " } 50.00 \text { and over } \\
& \text { for cash with order. }
\end{aligned}
$$

No discount from collection prices.

If order is to be billed please give bank reference.

Roots delivered after Sept. 1.

Transportation prepaid.

12 of a variety for 10 times price of 1.

The rating of each Peony is given when possible in front of the variety name.

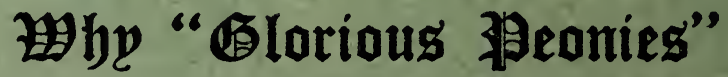

If there is a "noble" flower, it is the Peony.

\section{"Real Good Peonies For Every Garden"}

We are always glad to have customers and friends inspect our grounds at any time. Peonies are in good bloom from June 6th to the 20th.

\section{To Reach Us By Motor}

We are located on Peconic Bay Blvd. Follow state road east about 5 miles from Riverhead, turn right at Fischer's Garage, Jamesport, cross L. I. R. R. tracks, go to Peconic Bay Blvd., turn right and drive about $1 / 2$ mile to Nursery.

Coming from the East turn left at Fischer's Garage.

Not open for business on Sundays. 


\section{Grepting}

THIS is the fourth edition of my catalogue and will be in force subject to necessary changes until the supply is exhausted, when another edition will be revised and printed, thereby doing away with the expensive, and at times wasteful method of printing a new catalogue each season, whether changes are necessary or not. We will continue to specialize in the best there is in

\section{“便lorious 狂enieg”}

\section{and "Inovely Zilies"}

with an offering of a limited number of other

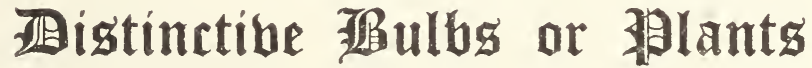

Peonies are delivered from Sept. 1 to the freezing of the ground.

Most of the Lilies can be delivered either fall or spring.

\section{Sincerely,}

I. S. HENDRICKSON.

Peconic Bay Blvd.

Jamesport, L. I., N. I.

Nay, 1931 


\section{Culture of 䚀onies}

The best time of all the year to plant Peonies is from about Sept. 1 until the ground freezes. October dug roots will have larger "eyes" than those dug Sept. 1, but they will not produce any better results. When you receive your shipment of roots soak them in water for several hours before planting. Prepare the ground by deep digging or plowing, working in some raw ground bone as a permanent food for the roots to feed on. Top dressings of wood ashes from year to year are very beneficial. Plant so the eyes are only about two iffches below the level of the ground and plant where drainage is good, as no water should stand where Peonies are to grow. Keep ground free from weeds.

It takes about three years for a Peony to become established so it will bear its finest flowers. Planted three feet apart each way the roots can remain undisturbed for a period of 5 to 10 years and each year develop into a finer plant. After the ground freezes cover a new planting with some straw, leaves or other litter to prevent heaving roots out of ground by the action of the frost. In the spring remove covering and cultivate frequently from April to September to insure the finest flower from year to year.

\section{The $\mathfrak{C u t} \mathfrak{J}$ lowers}

When cutting Peonies always leave two or more leaves on the stalk from which you cut and it is better not to cut all the flowers from any plant.

Leave some leaves on each stalk and some flowers on each plant. It pays.

\section{Size of hoot}

Do not make the mistake of thinking you need a large clump when you buy a Peony.

A clump may have 4 or 40 eyes and mean nothing. Your results will be better if you let your grower or dealer do the cutting and take the 3 to 5 eye division, which is now accepted as the standard size for best results.

Plant "Glorious Peonies" in your garden, but do not plant too deep if you want bloom. 


\section{羽eomíes}

\section{㚼ouble 田arieties}

Note varieties in bold face type.

Rating

8.5 Adolphe Rousseau (Mech 1890)--Semi-dbl. E. Mid. Tall. Dark velvety red with hues of garnet and a distinct metallic reflex. One of the best dark varieties. I.arge

A. J. Davis-A red variety similar to Adolphe Rousseau except it is lighter and brighter in color. Tall

8.7 Albatre-Milk white petals edged with line of crimson. A soft yellow tone reflected from the base of petals. The whole flower is very waxy and chaste and to our way of thinking is unbeaten by any other white. A superb variety

8.6 Albert Crousse (Cr. 1893)-Late. Tall. Delicate sea shell pink, very large and full. Convex bloom. Petals imbricated and overlap

8.8 Alsace Lorraine (Lemoine 1906)-L. Mid. Med. Rich creamy white tinted brownishyellow. Produces clusters of large imbricated flowers with pointed petals, with a center like a water lily

8.1 Asa Gray (Crousse 1886)-Mid-season. Guard petals salmon flesh, center delicate lilac sprinkled with minute dots of deeper lilac

7.3 Auguste Villaume (Crousse 1895) -Late. Tall. Deep rich violet rose. When season is favorable to it, it is a magnificent bloom. In form very compact and globular

7.8 Augustine d'Hour (Calot)-Dark brilliant solferino red, slight silver reflex. Tall free bloomer

8.0 Aurore (Dessert 1904)-Flesh pink tinted lilac. These large fragrant flowers of semirose type have a collar of lighter colored petals intermixed with stamens surrounding a center of wider petals, which are occasionally flecked carmine. A free mid-season bloomer, medium tall and erect 
9.0 Baroness Schroeder (Kelway 1889)-A flesh tined white merging to a milk white. In some flowers a glow of gold or baby pink seems suffused through the petals. Altogether an excelent variety

8.5 B ay adere (Lemoine 1910)-Mid. Med. Creamy white with a golden heart. Large globular flowers

7.2 Beaute de Villecante (Gom. 1856) - L. Mid. Med. Guards and crown violet rose collar lilac white. Fragrant

7.6 Belisaire (Lemoine 1901)-Mid. Tall. Pale lilac, splashed with minute dots of deeper lilac. Guards and center flecked crimson

8.1 Benjamin Franklin (Brand 1907)-Mid. Tall. Dark crimson, outer petals large and the center composed of smaller overlapping petals mixed with many stamens; faintly fragrant

7.8 Carnea Elegans (Calot 1860)-Mid. Med. Clear flesh pink with satiny reflex mixed with yellow narrow petals. Perfect in shape and charming in every way

Caroline Allain-Flesh-pink with s a $1 \mathrm{~m}$ on markings, opening up to white, the outer margin of the petals showing thin line of red

7.8 Charles McKellip (Brand 1907)-Midseason. Rich bright red. Silky, broad and crinkled petals form a symmetrical flower. Both habit of growth and foliage are good

8.6 Cherry Hill (Thurlow 1915)-Early midseason. Semi-rose type. Deep rich garnet red with a noticeable sheen. Retains the brilliant even tone until the flower has passed. Very profuse bloomer

8.4 Chesdine Gowdy (Brand 1913)-L. Mid. Tall. Silvery pink guard petals. Center cream with deep pink crown splashed crimson. Perfectly formed flower. Fragrant and choice

8.7 Claire Dubois (Crousse 1886)-Late Mid. Tall. Rich clear satiny pink with glossy reflex

7.5 Claude Gellee (Lemoine 1904)-Late. Dwf. Creamy white shaded Havana brown, some faint crimson flecks on center petals 
8.5 Clemenceau (Dessert 1920)-Late. Unusually large, full, imbricated bloom. Deep rosy carmine with silvery tints. Wonderfully free flowering. Long stems and beautiful flowers

8.1 Couronne D'Or (Calot 1873)-Late. Tall. White, slightly flecked crimson, reflecting golden stamens through the petals. Profuse bloomer and very desirable and popular

7.5 Delicatissima (Rosefield 1900)-Early Mid. Tall. Very large full flowers of clear even pink shading lighter at the center, very delicate color

Dr. H. Van Der Tak-Mid. Glistening crimson toward the center with lighter sheen on the incurved tips of the petals

7.7 Dorchester (Richardson) - Pale hydrangea pink. Fragrant. Medium dwarf. Free bloomer

8.1 Duchess de Nemours (Calot 1856)-Sulphur white without flecks except a touch of green at the heart that seems to light up the whole flower. Beautiful in the opening bud. Fragrant. Early. Medium to large flowers

7.6 Edulis Superba (Lemon 1824)-Early. Med. Bright clear deep pink. Very early and fragrant as a rose. Free bloomer. Used extensively for Memorial Day cut-flowers

7.8 E. G. Hill (Lemoine 1906)-Mid. Dwf. Rose-pink with lighter tints, showing now and then a few golden stamens

7.6 Ella Wheeler Wilcox (Brand 1906)-Late. Tall. Deep shell pink, the elevated cup shaped center is surrounded by many rows of irregular fringed petals, the outer ones sometimes rich cream. Fragrant

8.7 Elwood Pleas (Pleas 1900)-Mid. Tall. Delicate pink or white tinted pink. Very large and extra good flower

8.9 Enchanteresse (Lemoine 1903)-Late. Tall. Creamy-white, guards splashed crimson, cen. ter faintly flecked crimson

7.6 Euch a ris (Lemoine 1909)-Late. Med. Creamy-white compact globular flower. Fra- 
Rating

Each

8.6 Eugenie Verdier (Calot 1864)-Mid. Tall. Pale hydrangea-pink. Collar lighter. Deeper in center, flecked crimson

8.2 Evangeline (Lemoine 1910) - Mid. Tall. Pale lilac pink splashed with crimson. Imbricated petals. Good. Fragrant. Flat and very large

7.7 Fanny Crosby (Brand 1907)-Early. Med. Guard petals delicate pink surrounding a medium sized bomb of narrow incurved petals of deep lemon yellow

7.8 Faribault (Brand 1918)-Late. Med. Deep rose with silver sheen. Collar somewhat lighter than the guards. Silver tipped center petals fragrant

8.4 Felix Crousse (Crousse 1881) -L. Mid. Med. Deep ruby red. Center shading deeper. Large globular bloom of fine form

9.3 Festiva Maxima (Miel 1851)-Mid. Tall. An outstanding variety of over seventy-five years and is the most popular white variety today. Enormous white flower with carmine spots on edge of center petals. No garden is complete without Festiva Maxima

Fontenelle (Rosefield 1916)-Early. Tall. Clear brilliant crimson flowers of medium size

Fragrans-Mauve pink. Sweet as a rose

9.1 Frances Willard (Brand 1907)-L. Mid. Tall. This variety opens an exquisite blush-white with a carmine blotch now and then changing to pure white. Delicate in appearance but of good substance. One of the best yet produced

8.2 Francois Rousseau (Dessert 1909)-Rose. Early. Med. Brilliant velvety red showing golden stamens

Freedom (Kelway)-Very bright rose color, semi-double flower of extra large size

8.1 Galathee (Lemoine 1900)-Late. Tall. Fleshy white; large and very double; fragrant

7.2 Gen'1 Dodds (Crousse 1893)-Late. Tall. Uniform dark tyrian rose. Guards splashed green with a few white petals in center. Large globular and compact 
8.9 Georgiana Shaylor (Shaylor 1908)-L. Mid. Med. Large bloom with very wide petals of flesh pink changing to a delicate whitish flesh in center. A very lovely and satisfactory sort, dependable in every way year in and year out

8.5 Germain Bigot (Dessert 1902)-Mid. Med. Pale lilac rose. Center flecked crimson. Very good

8.2 Gismonda (Crousse 1895)-Late. Tall. Lively flesh pink with delicate rose center. The latest Peony of its color to bloom and a gem of the first water in habit, fragrance and form

7.9 Glorie De Chas. Gombault (Gom. 1866) Mid. Tall. Light rose, crown and guards shading to salmon, center flesh pink. Some petals striped carmine. Medium size globular flowers

7.0 Goliath (Hollis 1909)-Mid. Tall. Tyrian. rose slightly tipped silver. Extra large globular flowers with wide petals

8.8 Grandiflora (Rich. 1883)-Late. Tall. Uniform rose-white. Very large and flat. Une of the best of all times

8.1 Grandiflora Nivea Plena (Lemoine 1924) Rose. Early. Med. Guards milk-white, the collar cream white. Center petals have delicate salmon and sulphur tints

Grandiflora Rubra-A good red. American Beauty rose color

8.2 Grover Cleveland (Terry 1904)-Late. Tall. Dark crimson, very large and full flower. Fine upright bloom

Harry L. Richardson (Rosefield 1925)-New. Clear deep bright red or crimson. Perfect in form. Possesses an unusually sweet rose fragrance seldom met with in red peonies. Very late

8.1 Helen Wolaver (Brand)-Sea shell pink. Very dainty and very fine

8.8 Henry Avery (Brand)-Light pink, medium height, midseason. General color effect pink and creamy white. Has collar of bright yellow petals. Very fine variety

8.7 James Kelway (Kelway)-E. Mid. Med. Rose white changing to milk-white. Tinged yellow at base of petals 
8.3 Jeanne Gaudichau (Millet 1902)-White with pink reflex; petals edged with carmine. Large semi-globular flowers

8.9 Jubilee (Pleas)-Mid. Tall. Uniform blushwhite. A very large and flat flower

8.6 Judge Berry (Brand 1901) - Very early. Soft pink, changing to white flushed pink, producing a pleasing effect. Large flat blooms, forming a perfect dish. Medium tall, a free and reliable bloomer. The early blooming season makes it very distinctive

7.2 Jules Calot (Calot 1861)-Mid. Med. Dark solferino pink with silvery reflex. Fragrant

9.0 June Day (Franklin 1920)-Mid. Light oldrose-pink, with white outer petals graduating to a fine symmetrical rose-bud center, showing an occasional fine narrow crimson line in the middle of the flower and a few stamens in the collar; fragrance sweet but not strong. Medium height; vigorous; free-flowering; good stems. Broad, heavy foliage. A very handsome bloom, acquiring a delicate translucent color of the utmost clearness and purity as it ages

8.8 Karl Rosefield (Rosefield 1908)-Dark velvety crimson, clear and brilliant without a trace of purple. Very large, compact and of fine form. Semi-rose type. Early midseason. Strong and very erect stems that are medium to tall in height. Of all the reds this is about the best all around variety. A very reliable bloomer

9.8 Kelway's Glorious (Kelway 1909)-Second only to Le Cygne of the whites. Opens with a suffusion of flesh pink changing to white. Guard petals tinted pink and slightly streaked carmine on the back. Very large and full. High and globular with a cupped center. Rose type. Medium height and erect strong stems

8.8 Kelway's Queen (Kelway 1909)-Midseason. Its large, globular flowers have high built cupped centers. A uniform mauve-rose and a tinting of carmine-pink deep in the petals, liven up the blooms remarkably. Fragrant. Medium tall strong and upright grower with fine stems and broad, rounded foliage. Free and reliable bloomer 
Rating

Each

9.2 La Fee (Lemoine 1906)-Crown. Early. Tall. Rose pink with silvery light overcast. Collar creamy yellow; large globular flower. Fragrant

7.5 La Fiancee (Lemoine 1892)-Crown. Mid. Tall. Creamy white with base of petals shaded yellow. Center flecked crimson showing stamens

8.4 La Fontaine (Lemoine 1906) -Late midsea. son. Light violet-rose, very near to a true lavender, with the center petals tipped carmine. Very large blooms with prominent guard petals surrounding a compact globular center. Tall, upright, compact growth with strong stems

9.0 La France (Lemoine 1901)-Late midseason. Color La France pink, as the flower ages, finishing soft apple-blossom-pink reflecting mauve. The outer guard petals have a splash of crimson through the center deepening at the base. The flower appears to light up and glow; simply wonderful

8.6 La Lorraine (Lemoine 1901)-Mid. Med. Creamy white with faint salmon-pink tinge, large globular flower

8.5 La Perle (Crousse 1885) - Rosy flesh pink with a silver border and flecked carmine. Very fragrant. Very large, globular, compact flower of rose type. Late midseason. Medium tall, very strong and upright. Splendid for cut flowers and landscape use

8.3 La Rosiere (Crousse 1888)-Creamy white with a straw yellow center. Fragrant, large flat semi-double flowers that are most attractive when not disbudded, as all of the buds open at the same time, making a cluster of flowers on one stem. Early midseason. Nearly erect, and of medium height. A wonderful landscape variety

8.1 La Tendresse (Cr. 1896)-Rose. Early. Tall. Uniform milk-white guards slightly splashed and center flecked crimson. Large compact flat flower

7.5 La Tulipe (Calot 1872)-Mid. Tall. Blush or very light pink with carmine stripes on the outer side of the petals. Loose flat flower of semi-rose type. Strong and erect 
9.1 Lady Alexandra Duff (Kelway 1902)-Mid. Tall. Lovely French white. Central flower of rather flattened, circular form and the central petals have a touch of carmine. Side flowers come in semi-double, saucer-shape form, exposing the anthers. Finely formed flowers of great beauty and very fragrant

8.4 Lamartine (Lemoine 1908)-Rose. Late. Tall. Carmine rose, petals bordered silvery white. Large compact globular flowers -.--

9.9 Le Cygne (Lemoine 1907)-This splendid flower that rates the highest of them all is very appropriately named "The Swan." Its color is creamy white with a greenish tinge in the heart. An immense flower with incurved regular petals, and of a perfect rose type. Midseason and medium tall with strong stems. Not a fast grower, but gives typical bloom on young plants

8.8 Lillian Gumm (Gumm 1921)-Very large; late midseason. Outer petals large and ruffled, set edgewise to accommodate the greatest number of crowded center petals arranged in whorls; deep even rose-pink, suffused by chamois from the base of the petals; very fine fragrance. Tall; vigorous; strong, stiff stems. Excellent foliage

8.1 Livingstone (Crousse 1879) - Late Med. This large, very compact flower is perfect rose type; and the imbricated petals are uniform, pale lilac-rose, silvery tipped; center petals flecked with carmine. The plant-growth is strong and vigorous, with good sturdy stems. Both the buds and flowers are of large size and good form. A free bloomer. One of the best late varieties available at a popular price

9.0 Longfellow (Brand 1907)-Late midseason. Perhaps the most brilliant of all the red Peonies. Bright crimson with a cherry tint. A circle of golden stamens surrounds the central mass of petals while the outer ones are slightly reflexed

8.4 Lora Dexheimer (Brand 1913)-Early. Intense flaming crimson, shading darker at the base of petals 
Rating

Each

8.8 Loveliness (Hollis 1907) - These large, flat, rose type flowers come very late. The wellformed buds open slowly into perfectly formed blooms of uniform hydrangea-pink, changing to lilac-white. Fragrant. The growth is medium tall and upright with good strong stems. A beautiful flower that opens at the very close of the season along with Dorchester and Galathee

9.0 Mabel L. Franklin (Franklin 1920)-Outer petals light pink, center darker. Near the crown are intermingled short, creamy petals that add greatly to the beauty. Light margin of lavender on inner petals. Delightfully fragrant

8.7 Madelon (Dessert 1922)-Late. Very full, perfect form. Imbricated. Silvery pink tinged carmine. A new and superb variety 12.00

8.6 Mme. Auguste Dessert (Dessert 1899)-E. Mid. Med. Soft pink tinged carmine and splashed crimson. Fragrant, large flat flower with a conspicuous ring of stamens. Early midseason. A free bloomer and erect

8.1 Mad. Calot (Miel 1856)-Early. Tall. Pale hydrangea-pink, center shaded darker. Collar tinted silver

7.9 Mad. Camille Bancel (Crousse 1897)-Late. Med. Deep pink with silvery reflex center shaded salmon; fine

7.9 Mad. Crousse (Cal. 1866)-Mid. Med. Pure white with crimson fleck in center. One of the best whites. A real gem

7.9 Mad. De Verneville-Early Med. Blooms are very full and double with large pure white guard petals that fold over the flower. This white Peony is suffued with a dainty blush, making it one of the most charming varieties in existence. Very free blooming with true June rose fragrance

8.2 Mad. De Treyeran (Dessert 1889)-Early. Med. Tall. Rose-white freely splashed with lilac. Very attractive and fragrant

8.5 Mad. Emile Galle (Crousse 1881)-Late. Med. Tall. Large double cup shaped imbricated flower of a delicate sea shell pink suffused with lavender. A beautiful variety and one to make any one enthuse over 
8.9 Mad. Emile Lemoine (Lem. 1889)-Mid. Tall. Enormous buds opening into extra large imbricated round flowers with each petal overlapping the other giving the whole flower a distinctive even shape. Glossy white overlaid with a sheen of satiny pink covered at first with minute dots of lilac opening out purest white. I agree with Mr. John Wister, Pres. of the Iris Soc. that we have in this about everything desired in a white variety.

8.2 Madam Gaudichau (Millet 1909)-Mid. Tall. Very dark crimson-garnet. Large globular flowers

7.0 Mad. Geissler (Crousse 1880)-Mid. Med. Mauve-pink overcast with silver. Very large compact and globular flower. Imbricated ---

7.0 Madam Hutin (Crousse 1892)-Mid. Tall. Uniform deep violet rose

9.4 Mad. Jules Dessert (Dessert 1909)-Very large, imbricated flat bloom, pure white overlaid with a sheen of delicate blush deepening to a pink center intermixed with golden stamens. Best when cut in tight bud and allowed to open in the house. Destined to a great future

7.7 Mad. Loise Mere (Calot 1863)-Fleshy-white with silky reflex, with touches of carmine on border of petals

7.7 Mad. Savreau (Savreau 1906)-Early Mid. Tall. Lilac white guards and crown, with creamy yellow collar. Large compact globular flower

7.8 Mlle Desbuisson (Crousse 1892)-Late. Tall. Guards violet-rose. Center fading milk white

8.2 Marcelle Dessert (Dessert 1899)-Mid. Med. Milk white minutely splashed with lilac. Center flecked crimson; fragrant

8.4 Marguerite Gerard (Cr. 1892)-Late. Med. Very pale hydrangea-pink fading to nearly white. Central petals flecked dark crimson

8.9 Marie Crousse (Crousse 1892)-Mid. Tall. Pale lilac-rose; erect strong grower; large globular flowers 
8.3 Marie Jacquin (Verdier)-Mid. Med. A semi-dbl. type but very pleasing on account of its water lily like appearance. Glossy rosywhite with a rose tinge on buds. A wealth of yellow stamens give a golden reflection that is very pleasing. Strongly scented and a great favorite. When well established it of ten produces full double flowers of great beauty

8.5 Marie Lemoine (Calot 1869)-Late. Med. Ivory white, with now and then a petal tipped carmine

7.8 Marquis C. Lagergren (Dessert 1911)-Mid. Large, bright velvety-crimson with a distinct silvery border. One of the finest reds ever produced for both landscape and cut purposes

9.1 Martha Bullock (Brand 1907)-Tall. The largest of the good peonies. Deep rose-pink in the center, shading to silvery shell-pink in the outer petals. Stalk strong and erect. This unlike most large peonies, is a fine and delicate structure with a strong and agreeable fragrance which makes it most desirable and effective as a cut flower. Where a peony of enormous size, delicate structure, with soft, well blended colors and having a delightful fragrance is desired, it can be found in its highest degree of perfection

8.7 Mary Brand (Brand 1907)-This large, semi-rose type flower comes in midseason, and is a vivid crimson with a silvery sheen that gives it great brilliance. In color, it is not as bright as Longfellow, but the flower is larger. The blooms last long both on the plant and as a cut-flower. It is a medium-tall grower, with good habits and good strong stems. A good landscape plant as well as a good cutting variety

9.0 Mary Woodbury Shaylor (Shaylor 1916) Late. Med. Guard petals fresh clear pink with a creamy colored collar, and a canary golden color at heart. Dwarf habit with stiff stems. An added advantage of this late variety is that it always develops well

7.9 Mathilde DeRoseneck (Crousse 1883) - Late. Tall. Pale lilac-rose with deep carmine center; large globular flowers 
Rating

Each

7.3 Midnight (Brand 1907)-Early. Tall. If this red peony had substance enough in its petals to better endure the hot sun, it would be one of the most popular varieties. The flowers are very large, semi-double, with broad petals of rich, dark red. They open early on a tall, graceful plant and always attract much attention, but unfortunately they do not hold well in the sun and wind

8.7 Mignon (Lemoine 1908)-Mid. Med. One of the most charming of all $M$. Lemoine's wonderful varieties. The large, compact flower is of globular, semi-rose type and the petals are broad, imbricated, and symmetrically arranged. They open into large, flattopped, ball form, developing to a flat flower, and the color is lacy white, changing to amber-cream, with the center petals flecked carmine. The plant is medium tall, very erect, well set with luxuriant light green foliage, and the stout stems support the flowers perfectly

9.0 Milton Hill (Richardson) - Late. Med. This late-blooming variety is one of the very finest Peonies. Its flowers are very large, delicately colored, and have refined texture. The broad petals are slightly incurved and open in globular, cupped form,developing to a large, flat flower of perfect rose-shape. It is pale lilacrose, or flesh, with opalescent tints of delicate salmon-pink

7.7 Mireille (Cr. 1894)-Late. Tall. Milk-white. Large center petals edged dark crimson. Fragrant

7.8 Miss Salway (Kelway)-Early Mid. Lilac white with lighter collar. High crown. Tall strong grower and free bloomer. A very fine variety

7.8 Modele de Perfection (Crousse 1875)-Late. Med. Guards and collar light violet rose, very wide high center petals shaded darker; fragrant

7.8 Modeste Guerin (Guerin 1845)-Early midseason. Color a uniform solferino-pink tinged carmine. Best Peony of its color to bloom at this season 
Molly Stark (Auten 1927)-Develops a high cone and tuft on mature plants. Guards pale pink, cone pale yellow, red splashes in center. Rose fragrant, free flowering, very early; plant and stem good, valuable for cutting or landscape

Mons. Dachutre (Kelway)-Medium shade of soft pink splashed with a darker pink throughout the flower. Very large and compact with a high crown. Midseason, medium height, and nearly erect

8.3 Mons. Dupont (Calot 1872)-Mid. Tall. Milk white, center splashed crimson. The golden stamens, showing at the base, greatly adds to the beauty of this variety

9.2 Monsieur Jules Elie (Crousse 1888)-Early. Med. Very large and full globular; finest glossy flesh pink, deepening at the base of the petals, reflex silvery pink, broad, overlapping petals; strong, vigorous grower and free bloomer, probably the finest and most perfectly formed pink Peony in existence

7.7 Mons. Krelage (Crousse 1888)-Deep currant red. A distinct color. Large compact, semi-rose type flower that blooms at late midseason. Medium height and erect

8.8 Mons Martin Cahuzac (Des. 1899)-Mid. Med. Very dark purple garnet with black reflex

8.4 Mont Blanc (Lem. 1899)-Early. Mid. Tall. Milk-white, center slightly tinted rose. Fragrant

7.8 Mrs. Carew (Brand 1907)-Large, full, rose shaped flower. Delicate silvery blush, some inner petals with carmine edges

9.3 Mrs. Edward Harding (Shaylor 1918)-Mid. Tall. A large, pure white having close-set petals of fine quality and pleasing form. A plant of ideal habit; strong, upright and vigorous on well established plants, a free and and reliable bloomer 
Rating

8.2 Mrs. John M. Lewis (Lewis 1920)-A distinct variety of exceptional merit. The large flowers of semi-rose type are variable in their development, sometimes coming with many rows of petals surrounding a center of yellow stamens, and at other times coming almost full double with the stamens mingled throughout and almost wholly concealed. An attractive shade of deep, velvety, ox-blood-red that holds without burning in the hottest sun. A medium tall plant with strong, upright stems.

Midseason

8.5 Octavie Demay (Calot 1867)-A delightful variety of dwarf growth that blooms early, just when the flowers are most appreciated. The blooms are large, crown type, with guards and center pale hydrangea-pink and the collar almost white. The guard petals reflex to the stem. A free bloomer on strong, upright stems

7.4 Old Silver Tip (Brand 1918)-Mid. Med. Soft madder-rose with silver sheen

Othello (Lemoine 1916)-Medium size flower; very double; color deep crimson with blackish bronze shading. One of the darkest Peoniest in existence

7.2 Paul Fischer (Rich.)-Mid. Tall. Pale lilac rose

8.5 Petagra (Franklin)-The very large, loose, light red flower has a circle of golden stamens surrounding the center petals, and the guard petals show light green stripes on the lower side. A tall, strong grower. Fragrant

9.2 Phillipe Rivoire (Riviere 1911)-Early. Tall. Large well formed cup-shaped flower; very dark crimson with tea rose fragrance

8.8 Phoebe Carey (Brand 1907)-Late. Tall. Beautiful rose-pink, center deeper. Petals large broad and of good substance

7.6 Pierre Dessert (D. \& M. 1890)-Early. Tall. Dark crimson-purple, silvery tipped

8.2 Pierre Ducharte (Cr. 1895)-Late. Med. Flesh-pink with silvery sheen

7.6 Pierre Reignoux (Dessert 1908)-Early. Dwf. Uniform light Tyrian-rose, center slightly flecked crimson; petals imbricated

Pink Lady (Pleas)-A very dainty, semidouble shell pink. Very fine as a cut-flower 
7.7 Pres. Roosevelt (Warnaar 1905)-Midseason. A distinct shade of brilliant dark red. Medium size, globular flowers. A medium tall, erect plant with slender and stiff stems

8.7 Pres. Taft (Reine Hortense) (Calot)-Delicate center, flecked with crimson surrounded by white. Very attractive. Free bloomer, tall and vigorous

8.6 Primevere (Lem. 1907)-Mid. Tall. Yellow. Large, prominent, creamy-white guard petals inclosing a central ball of sulphur-yellow. If cut in the bud and it begins to open, and developed inside, away from the sun, the flowers will hold a canary-yellow color which is very beautiful. Fragrant

7.2 Purpurea Superba (Del. 1855)-Mid. Tall. Uniform deep carmine-rose. Guards streaked white. Large globular compact flowers

8.3 Rachel (Lemoine 1904)-Lively soft pink, darker when just opening. Large globular shape of beautifully formed petals. Fine form, vigorous growth, stiff, erect stems and profuse blooming qualities are some of the merits of this superior variety

9.0 Raoul Dessert (Dessert)-Large blooms with broad petals of shell-pink with deeper gleams. Distinct and fresh coloring. Late midseason

8.7 Reine Hortense (Calot 1857)-Mid. A soft hydrangea-pink which is always considered an exquisite color. The center of the flower is flecked crimson which adds to its beauty. All things considered it is an extra fine sort and indispensable in a collection

8.8 Richard Carvel (Brand 1913)-Early. Tall. Very bright crimson. Large compact globular flower

8.0 Richardson's Perfection (Rich. 1869)-Late. Tall. Pale shell pink or lilac white; base of petals shaded deeper

9.0 Rosa Bonheur (Dessert 1905)-Mid. Med. Light violet rose; guards flecked crimson; petals imbricated

7.1 Rosy Dawn (Pleas. 1909)-Mid. Med. Rosepink with golden stamens intermingled, filling it with tints of daybreak 
Rubra Triumphans-Mid. Tall. Dark purplish crimson; large loosely built flowers which last a long time after being cut

9.0 Sarah Bernhardt (Lemoine 1906)-Late. Med. Very large perfectly double rose formed flowers the color of apple blossoms

7.9 Simonne Chevalier (Des. 1902)-Mid. Med. Deep shell-pink with lighter collar

9.7 Solange (Lem. 1907)-Late. Med. One of the premier varieties being only three-tenths of a point from perfection in rating. Full globular flowers with a compact crested tuft in the center. Color is deep orange salmon or Havana-brown at the heart overlaid with a delicate reddish-brown. An outstanding variety in every sense of the term and very late. The roots of this variety often look poor but they will bloom

8.0 Stephanie (Terry)-Late Mid. Tall. Creamy white with golden reflections from stamens at base of petals. Very fragrant

7.7 Suzanna Dessert (Dessert)-Pink with silver tips. Large and full clustered

8.0 Suzette (Dessert)-Bengal rose, slightly shaded carmine purple with silvery reflex. Shows stamens

8.3 The Gem (Pleas. 1909)-Mid. Tall. Brilliant dark crimson flowers compact and beautiful. Produces oreat clusters when well established

9.8 Therese (Dessert 1904)-Midseason. One of the three highest rated Peonies. Color rich satiny pink with glossy reflex. Flowers are enormous in size of full rose type. Sturdy, vigorous grower with upright stems and rich green foliage. Delicately fragrant. Always creates enthusiasm. It is truly a "Glorious Peony" and one of the most popular

9.4 Tourangelle (Dessert 1910)-Late midseason. Pearly white overlaid with delicate salmon and la France pink tints. Exquisitely beautiful in form and color

7.8 Triomphe De L'Exposition De Lille (Calot 1865)-Mid. Med. Pale hydrangea-pink minutely splashed violet rose. Guard petals fading to nearly white. Fragrant 
7.4 Umbellata Rosea (Dessert 1895) - Very early. Large flower, guards violet-rose shading to an amber-white center

8.3 Venus (Kelway 1888) - Late midseason. Pale hydrangea-pink, collar lighter. Delightfully fragrant. The plant is very strong and upright. Distinct broad, light green foliage. Fine for cut flowers

8.2 Victoire DeLaMarne (Dessert 1915)-Mid. Med. Tall. Velvety amaranthe-red with silvery reflex

9.3 Walter Faxon (Richardson 1904)-Mid. Outstanding in color; soft coral-pink shaded lighter at the ends of the petals and a deeper rose-pink at the base, with a salmon reflection. Medium to large size flower, globular in form with a cupped center. Medium tall and vigor. ous grower

8.3 Winnifred Domme (Brand 1913)-Dbl. type; Mid. Guards narrow and widely separated from the center which is high built and incurved, dark maroon-red throughout

(2)

\section{Japanege 羽onies}

8.1 Akalu-Crimson-carmine, large flowers

8.0 Altar Candles (Pleas. 1908)-Mid. Med. Guard petals are delicate pink which upon opening disclose numerous rounded petals like wax candles, each one tipped flame color. Blooms in clusters

9.2 Ama-No-Sode-One of the finest of this type. Evenly rounded petals forming a cupped shaped flower of bright rose pink, with a globular center of beautiful wide yellow petaloids, edged golden and faced with pink. 10.00

8.9 Aureolin-Delightful pink and yellow -.- 3.50

8.1 Cathedral-Blush with cream colored central filament petals

8.2 Flashlight (Hollis 1906)-Early. Med. Guards light Tyrian rose, narrow center petals amber yellow shading pink at base 


\section{Japanese Peonies-Continued}

Rating

Each

Foaming Wave-Carmine rose, very choice- 4.00

7.9 Fuji Mine (Japan)-Early. White. Central filament petals tipped yellow

9.2 Fuyajo-A rich dark maroon with velvety shading. Two rows of guard petals, center petaloids striped crimson and white. Very outstanding and desirable

9.3 Isani Gidui-Pure white with sulphur shades. Yellow stamens. Very large and fine. One of the best

Karafune-Early Med. Soft lavender, with salmon thread like petals

8.6 King of England (Kelway)-Rich ruby madder; long narrow central petals pure gold changing to gold striped carmine

8.6 Mikado-Dark crimson with narrow filamental petals edged crimson and tipped gold

7.6 Petite Renee (Des. 1899)-Anemone. Mid. Med. Collar clear carmine-purple, central petals very narrow clear carmine striped white, yellow background

Rose of Nippon-Very deep rose, the broadly prominent center darkened by carmine, and illumined by countless star points of both silver and gold. Many centers are slightly tufted

8.2 Snow Wheel-Pure white, yellow center

9.0 Some Ganoko-Very dark red. Extra fine. One of the best. Satiny reflex petals. Yellow center

8.9 Tokio-Clear carmine rose

9.0 Tora No Maki-Guard petals lilac white. Cushion center of white and clear amber yellow

8.0 Torpilleur (Dessert)-A very deep rose red in color, with rose center petals tipped cream

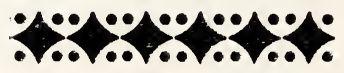




\section{Single 唒enies}

Rating

Each

Catherine Parry-Single. Early. Tall. Delicate shell pink shading to flesh-white. Very large flower

8.2 Darkness-Dark maroon red shading darker at base

8.6 Le Jour. Sgl. (Shaylor)-Pure white with yellow stamens showing red stigmas. Heavy substance

8.4 L'Etincelante (Dessert 1905)-The flowers are very large and cup shaped, with broad petals of bright pink distinctly margined with silver; center stamens bright yellow. A tall, fine plant that commands attention in any planting

Lord Kitchener (Kelway)-The finest rich red. Color deep uniform brilliant crimson of very glossy texture

8.5 Madeline Gauthier (Dessert 1908)-Silvery flesh pink surrounding a clean center of golden stamens. Perfect in form of flower and habit of growth. Very distinctive

8.5 Marguerite Dessert (Dessert 1913)-Very large, pure white, powdered and splashed with carmine; central tuft of golden stamens. One of the most exquisite varieties

Mischief (Auten 1925) - This charming single Peony has attracted much favorable comment at recent exhibits on account of its perfect form and pleasing color. It is a uniform soft pink that blooms late after most of the single flowers have passed. The blooms last well, and are borne freely on a plant of excellent habits

8.6 Nellie (Kelway) - A very large flower of uniform shell-pink. The petals are long and rounded, symmetrically arranged around the center of yellow stamens. It is a medium-tall grower, with strong, upright stems that support the flowers well

8.9 Pride of Langport (Kelway)-A beautiful bloom of bright peach pink. A lovely variety 


\section{Callections of “Glorious 狂omieg”}

\section{"Butstanding" Collection of 25 Earieties for $\$ 35.00$}

You will find the names and descriptions of this great collection in bold face type in the preceding pages.

At list prices they come to $\$ 48.75$, but as a collection you get them for $\$ 35.00$.

\section{“侯arly to Iate" Collection}

In this group we have tried to give you Peonies to cover a long season of bloom and to give you a fine assortment of colors and types.

Edulis Superba (pink)

Festiva Maxima (white)
Albatre (white)

Karl Rosefield (red)

Late

Albert Crousse (fresh pink) Felix Crousse (red)
Octavie Demay (hydrangea pink) Midseason Richard Carvel (red)

Mons. Jules Elie (pink) Philomele (rose pink, yellow reflex)

Gismonda (pink) Mireille (white) One 3-5 eye root of each for $\$ 15.00$

\section{“㑨agle" Collection}

5 for $\$ 5.00$

Jas. Kelway (white) Karl Rosefield (red) Livingstone (pink) Reine Hortense (variegated) Solange (rare Havana brown)

An unusual value.

\section{$\$ 10.00$ "Gurprise" Callection}

For $\$ 10.00$ we will send you 25 Peony roots with 2 eyes or more and at least 15 of them named and labeled of our selection; the other ten may be just mixed, but you will get splendid value for your money if you just want flowers and color and not particular about varieties.

We endeavor to assemble our collections with care and judgment and we believe they give the buyer an exceptional value. 


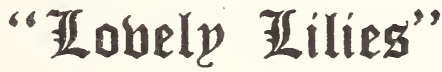

\section{(The Hardy Ones)}

Hardy Liliums occupy a very important place among the hardy plants as they are very effective in the flower or shrubbery border and do well in such situations, as they like some shade and ground cover that will keep their roots cool and moist.

Messrs. Barr \& Sons of England give this splendid summary of cultural directions:

"A cool rooting medium in open porous soil;

perfect drainage; and shade from hot sun."

If manure is used it should be only old well rotted cow or horse manure and then principally as a fall mulch.

Lilies revel in leaf mould and granulated peat moss and it can be used without fear of harm.

If soil is heavy or sticky, mix sand freely with soil and place some around the bulb when planting.

Liliums should be planted at least twice the depth of the bulb and the stem rooting varieties still deeper.

We have tried to give habit of and depth to plant each variety as far as possible.

\section{Auratum}

Imported bulbs for Dec. or Spring delivery.

The old and well known "Golden banded Lily."

White ground with bold bands and maroon spots. Hgt. 3 to $4 \mathrm{ft}$. Plant 8 inches deep.

$$
50 c \text { each. }
$$

\section{Batemanniae}

Color rich glowing apricot unspotted. Umbels carry 4 to 6 upright flowers of easy culture. Stem rooting. Plant 4 to 6 inches deep. August flowering. Hgt. $2 \mathrm{ft}$. 40 c each. Sept. del. 


\section{Candidum}

\section{Madonna Lily}

Fine large pure white fragrant flowers loved by everyone. Easy of culture but leave undisturbed after planting, which should be done by Sept. 15". Base rooting. Cover about 2 inches. June-July flowering. Hgt. 4 to $5 \mathrm{ft}$.

Selected bulbs from north of France. They are the best.

Orders booked for August-September delivery, when they should be planted as soon as received. Cover 2 inches deep.

50c Each; $\$ 5.00$ per Doz.

Smaller Size, 35c Each; $\$ 3.50$ per Doz.

Planted among Delphiniums they are exquisite.

\section{Hansoni}

A native of Korea but of easy culture nearly everywhere. It bears 6 to 12 fragrant nodding wax-like flowers with reflexed petals of stout texture; bright golden yellow spotted with brown; attractive foliage. Stem rooting; plant 6-9 inches deep. Likes plenty of leaf mould. June flowering: 3-4 feet.

Strong flowering bulbs $50 \mathrm{c}$ each $\$ 5.00$ per doz.

Extra " " $75 c$ " 7.50 " "

September delivery

\section{Henryi}

(The Orange-yellow Speciosum)

A very hardy free flowering Lily, reaching a height of 6 or 7 feet when well established, bearing up to 20 reflexed flowers of a deep orange-yellow, well set off with deep green foliage. Without doubt one of the best garden Lilies ever introduced. Stem rooting. Cover 6-10 inches. Sept. flowering.

Strong flowering bulbs $50 \mathrm{c}$ each $\$ 5.00$ per doz.

Extra " " $75 \mathrm{c}$ " 7.50 " "

November delivery 


\section{Regale}

\section{"The Royal Beauty"}

This is the "Wonder Lily" discovered by Mr. E. H. Wilson in China and one of the most adaptable to cultivation in ordinary garden soil yet found. Does not do well on rich ground.

The flowers stems are slender and flexible but strong enough to hold the crown of trumpet shaped blooms. The outside of the flower is streaked brown shading off to pink. The inside is pure white with a silver sheen on the face and clear canary within the tube, against which the golden anthers give a delightful reflection. Stem rooting; cover 6 to 10 inches deep. Hgt. 3 to 6 feet. July flowering. Can endure lime but revels in leaf mould or peat.

Extra ${ }^{\text {Strong flowering bulbs }} 30 \mathrm{c}$ each, $\$ 3.00$ per doz.

\section{Tenuifolium}

The lovely Coral Lily of Siberia.

Deep scarlet recurved flowers on slender stems covered with narrow foliage. Stem rooting. Cover 4 to 6 inches deep. Hgt. 18 to 24 inches. June flowering. Flowering bulbs, 6 for $\$ 2.00 ; 12$ for $\$ 3.50$.

\section{Tigrinum}

The Tiger Lilies are valuable for border planting, easy for culture and long lasting with just ordinary care.

Tigrinum Splendens-Fine old orange-red spotted purple on reflexed petals.

Tigrinum flora-plena-The double form of the Tiger Lily which is very pleasing. Stem rooting. Cover 7-9 inches. Sept. blooming. Hgt. 4 feet.

Flowering bulbs $25 \mathrm{c}$ each, $\$ 2.50$ per doz.

Selected " $\quad 35 c$ " $\$ 3.50$ " "




\title{
Elelegang $\mathbb{C} p \mathfrak{p}$
}

\author{
From Japan
}

They are dwarf growing early flowering Lilies adapted to group planting. The flowers are upright, cup shaped and most effective. Stem rooting. Plant 4 to 6 inches deep. June-July flowering. 12 to 18 inches high.

Aurantiacum Verum-Clear mikado orange without spots. Very effective.

Flore Pleno-Double set of petals. Light yellow, spotted brown.

Grandiflorum-Orange-red, light center, darker tips; faint brown spots.

Incomparable - Deep blood red, shaded lighter.

Kikak-Light apricot, spotted brown. Extra good.

Leonard Joerg-Fine shade of apricot with dark spots.

Orange Queen-Une of the finest forms. Bright orange color; petals are broad, rounded and heavy texture.

Prince of Orange-Soft buff spotted maroon; very dwarf; only about 10 or 12 inches.

Rosea-Brazil red shaded lighter toward center; few spots.

Sanguineum-Dark red with a few black spots.

Semi Pleno-Semi double. Coral red shading to orange chrome in center; few fine spots.

Good flowering size bulbs: 6 for $\$ 1.75 ; 12$ for $\$ 3.00$

Assorted Elegans Type-mixed colors: $\$ 2.00$ per Doz. Ready Sept. 1

\section{ambellatum $\mathbb{T}$ ppe}

\section{From Europe}

A showy section of Lilies of very easy culture. Stem rooting. Cover 6 to 8 inches deep; flowering in June ranging from 18 to 30 inches in height.

Erectum-The outstanding Umbellatum variety. Attractive form and very vigorous grower. The ground color is red with center of each petal flushed orange. Faint dark spots. 18 to 24 inches. Blooms in June.

Golden Fleece-Clear golden yellow suffused scarlet at tips of petals. Good.

Grandiflorum-Light orange red flowers.

Incomparable-Fine vigorous rich crimson.

Sappho-Orange-red, tips of petals flushed red.

Good flowering bulbs, 6 for $\$ 1.75 ; 12$ for $\$ 3.00$

$$
\text { Ready Sept. } 1
$$




\section{Speciosum or Japan IIIlíes}

A beautiful type of Liliums blooming in the Autumn after other Lilies except Henryi are gone. The flowers are large with reflexed petals which last well when cu: and placed in water; fragrant. Stem rooting. Cover 6 to 8 inches deep. Use no lime but they like plenty of mulch such as leaf mould or peat. Height 2 to 4 feet depending on age and soil.

As the varieties, Magnificum, Melpomone and Rubrum are so hopelessly mixed and have been for many years making it impossible even to import them true to name I have decided it the better way to just offer them as Speciosums rather than under separate varieties. After all, the general description of each is very similar and I think one is as pleasing as the other.

They have a white ground color suffused, splashed and spoted with ruby carmine, dark crimson, rose, etc.

\section{Strong flowering bulbs $40 \mathrm{c}$ each}

Extra " " $50 c$ "

Speciosum bulbs ready after Oct. 15

Watertown, N. Y.,

June 2, 1928.

I. S. Hendrickson,

Dear Sir:

The collection of "Glorious Peonies," as you call them, that I purchased from you late last fall and I set out 26th of October are all coming along fine. They certainly look good now. All of them quite tall with good stocky stems on them. About five of them have some very good buds formed and I am sure they will bloom this year.

Yours truly,

G. H. B. 


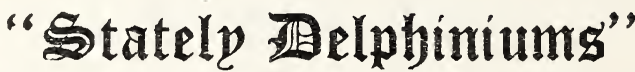

Nearly everybody loves the exquisite blue shades of the Hardy Delphiniums. We sow the best seed we can buy from the foremost specialists, as well as saving seed from the best of our own plants, with the result that we can assure you of getting some very beautiful varieties if you leave the selection to us or you can do as many of our customers do, come and select them yourself when in bloom as they can be transplanted almost any time. Delphiniums are subject more or less to the "black spot," which often causes them to disappear after 2 or 3 years. The plants we sell are young seedlings, kept as healthy as possible by dusting with tobacco dust from time to time.

\section{Culture}

With careful planting, plenty of water for a week or two, a feeding now and then of bone meal, wood ashes, and a complete fertiliżer used one after the other during the growing season, dust with tobacco dust several times and you will have good results.

After the first flowers fade, cut the stalk off within 6 or 8 inches of the ground, fertilize with one of the above, and a second growth of flowers will reward your efforts.

\section{Hybrids}

One year plants $50 \mathrm{c} \quad \$ 5.00$ per Doz.
Two "e "e $1.00 \quad 10.00$ "

Delphinium Belladonna--Light Blue

Delphinium Bellamosa-Dark Blue 35 c each; $\$ 3.50$ per Doz.

My dear Mr. Hendrickson:

Phila., Dec. 1, 1929.

In the spring you sent me some roots of Helleboris Niger (Christmas Rose) of which I requested especially good plants. I want to report that they are all budding or blooming and I am every happy over them. Thank you for the good stock.

Yours respectfully,

MRS. M. H. W. 


\section{理icentra Spetabilis}

Bleedingheart

An old-fashioned plant still loved by everybody.

Long racemes of rose-colored heart shaped flowers are produced in May.

A lovely and graceful hardy perennial fine for border planting. $50 \mathrm{c}$ each.

\section{Japan J Jrís}

\section{July Flowering}

For best results plant on a slope or other well drained situation. While they are forming buds in June, water or liquid cow manure is very beneficial. Well rotted manure or humus keeps them thriving. They do not seem to like lime or bone meal.

CATHERINE PARRY-Dbl. Blue overlaid rosy-red, high tufts in center almost triple.

ELEANOR PARRY-Dbl. Claret red, flamed white and blue. Compact medium size flower. Good.

JEANNETTE PARRY - Sgl. White suffusted with lines of bluish violet. Petaloid stigmas amethyst violet.

MARGARET S. HENDRICKSON-Triple. Soft bluish violet, large wavy petals. White center with cast of blue radiating therefrom.

MARJORIE PARRY-Dbl. Delicate light mauve, tufted center. Extra fine.

$50 \mathrm{c}$ Each; the Five for $\$ 2.00$

I. S. Hendrickson,

Dear Sir:

I received two "Christmas Roses" from you about three years ago. They did wonderfully well this fall, blooming from the first of November through January. They were a real joy to me and quite a curiosity to most everyone else, as they are very unusual here.

Very truly,

MISS N. R. 


\section{NOTES ON CHRISTMAS ROSES}

FVERY garden should boast some of those lovely D Camellia-like blossoms of the Christmas Rose that form a continuous chain of beauty in the garden, the connecting link between the last flowers of autumn and the first flowers of spring. These are not Roses or anything like Roses, except that they have the form and stamens of the wild Rose. They belong to the Helleborus family, near relatives of the Peony and Trollius. They have strong roots and leaves from the ground. Helleborus, the lovely Christmas Rose, has shining foliage growing about one foot high, from the midst of which during mild spells all through the winter and until the first days of spring, come large milk-white flowers, that soon become delicately flushed with pink and gradually grow darker until they are a deep rose color. These should be cut as they turn to delicate pink, and are lovely for household decorations. The plants will continue to bloom for several months if the blossoms are kept cut.

Small roots are almost as good to set out as large ones, for the plant must make new roots before it will bloom. It must be in the ground for about a year before it will start to throw out new eyes, as the new roots must be fully established before new growth begins above ground. If the summer is a very dry one and the roots all dry out, which is apt to happen to small plants if you do not water them, they will lose a year's growth. For again new roots will have to form before the plant can expand above ground. Few plants repay careful planting better than the Christmas Rose.

A liberal mixture of manure with the soil at the bottom of the hole where the plant is to go, quantities of water during the first season the roots are in the ground, the gift of bone meal in the fall,-this advance attention will result in sturdy plants and a wealth of blooms. The plants should be set out where they will have shade in summer and plenty of sunlight in winter.

Above everything plant your Christmas Rose where you will be sure to see it when it blooms and where you want it to stay.-Julia $\mathrm{H}$. Latimer. 


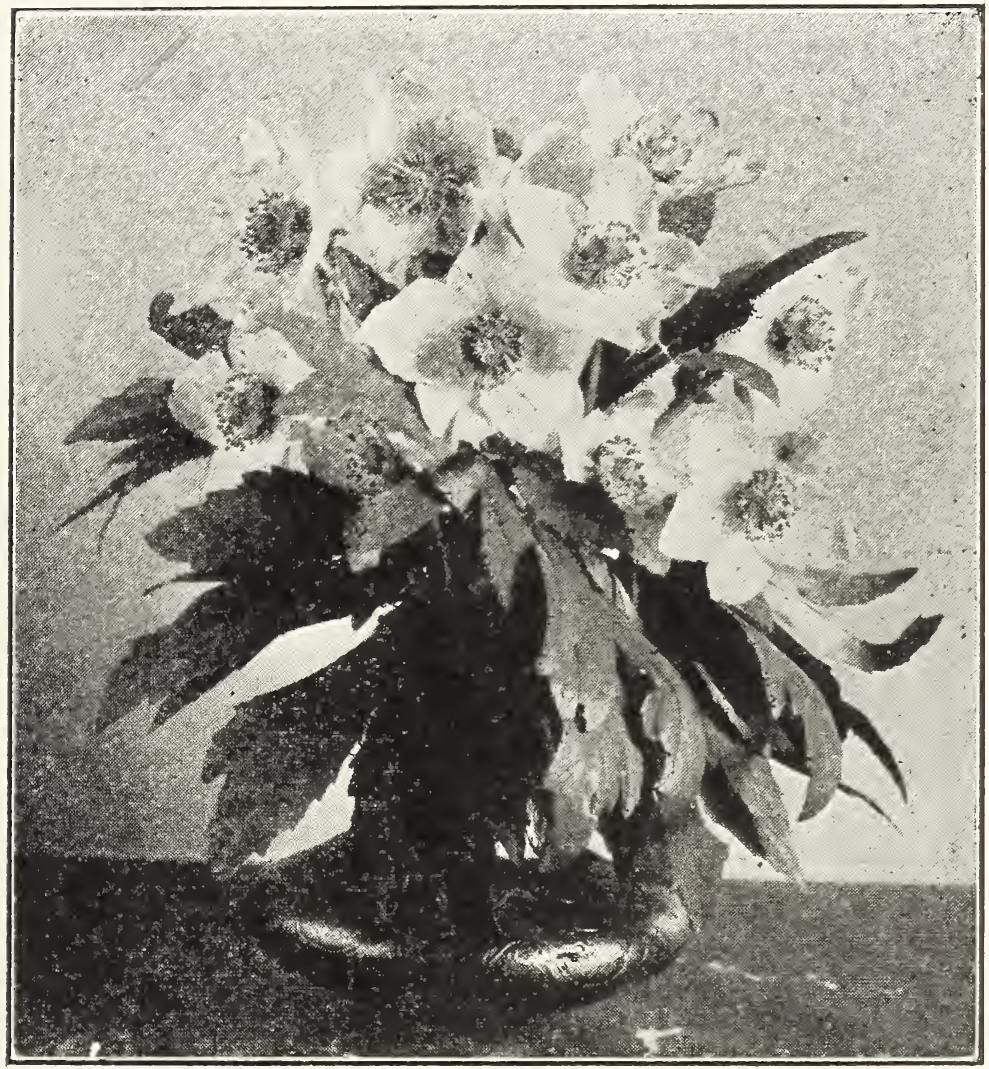

Vase of Christmas Roses

HARRY LEE PUBLISHING COMPANY, INC., RIVERHEAD, $N$. $\mathbf{T}_{\text {. }}$ 




\section{The Christmas æhose}

\section{(Helleborus Niger)}

A rare and delightful hardy plant blooming outdoors during mild spells all Winter and on into the Spring, often sending its large milk white flowers, which are of good substance, up through the snow at Christmas time, forming a connecting link between the last flowers of Autumn and the first ones of Spring.

Customers write us it is such a pleasure to dig away the snow and find these brave flowers nestling there.

Can be planted spring or fall. The plans we send out have a balanced growth of roots and foliage, insuring quick recovery from the transplanting.

\section{Culture}

When your plants are first received plunge them in a pail of water for an hour or two, then select a sheltered place in the border or garden where they can remain for several years; dig the place deep and when ready to set out do it just as you would a strawberry plant, that is, spread the roots out well and firm the earth around the roots up to the crown. If it's a dry season water the plants thoroughly several times to insure a good start.

When planted late in the fall they should be mulched to keep from heaving out before the roots are formed.

They like moisture but not "wet feet".

They are slow in getting a foothold and resent frequent moving. Left undisturbed your plants will give you an increase of lovely flowers each year.

\section{Legends of the Christmas Rose}

Out of pity an angel allowed Adam and Eve to take this one flower (the Rose of Affection) with them when driven out of the Garden of Eden.

In the Alsatian Mountains, where the Christmas Rose is found quite abundant, it is said that this flower first came into bloom at the hour of the birth of the Christ Child and has ever after been known as the Christmas Rose.

The hills are white in robes of snow But lo, upon the Winter's breast Amid the gleam of frost and ice The Christmas Rose uplifts its crest.

It seems the soul of Summer flowers Grown brave to cheer the Winter hours. (Edith Willis Lynn.) 